\title{
Transfer Hydrogenation; a Convenient Method for Removal of Some Commonly Used Protecting Groups in Peptide Synthesis
}

\author{
By Gattadahalli M. Anantharamaiah and Kadlebal M. Sivanandaiah," Department of Chemistry, Central \\ College, Bangalore University, Bangalore 560001, India

\begin{abstract}
$N$-Benzyloxycarbonyl and benzyl ester groups in peptides can be conveniently removed by transfer hydrogenation with cyclohexene and $10 \%$ palladium-carbon catalyst. If freshly prepared palladium black catalyst is used, other commonly used protecting groups like $N^{\tau}$-benzyl (histidine), benzyl ether (tyrosine, serine), and nitro (arginine) can also be removed much more rapidly than in the case of the usually employed catalytic hydrogenation.
\end{abstract}

THE reduction of mono- and poly-nitro-aromatic compounds rapidly, selectively, and in high yield by transfer of hydrogen from cyclohexene in the presence of palladium-charcoal was reported recently. ${ }^{1}$ We report here that transfer hydrogenation is also very useful for the removal of several protecting groups commonly used in peptide synthesis. Groups like $N$-benzyloxycarbonyl, C-terminal benzyl ester, nitro of nitroarginine, $N^{\tau_{-}}$ benzyl of $N^{\tau}$-benzylhistidine, and $O$-benzyl ether of $O$-benzyl-tyrosine or -serine are usually removed by catalytic hydrogenation over palladium-charcoal or palladium black. This method, though satisfactory in the case of $N$-benzyloxycarbonyl and benzyl ester groups, takes longer for the removal of other protecting groups. Indeed, hydrogenation for $2-3$ days over palladium black may be necessary for the removal of the nitrogroup from nitroarginyl residues in peptides, and even then the reaction may not be complete. Further, conversion of a nitroarginyl residue into an aminoguanidino-derivative ${ }^{2}$ and reduction of the aromatic ring of a phenylalanine residue, ${ }^{3}$ if present, are other complicating aspects of this procedure. The final product may therefore need extensive purification. Our own experience of catalytic hydrogenation of several nitroarginyl peptides has shown that the product is invariably contaminated with closely related impurities.

Transfer hydrogenation is a simple and convenient

1 I. D. Entwistle, R. A. W. Johnstone, and T. J. Povall, J.C.S. Perkin I, 1975, 1300 . method for removal of all protecting groups that are normally removed by catalytic hydrogenation. The protected peptide is dissolved in a mixture of ethanol and cyclohexene (acetic acid may be added to assist dissolution) and the solution is refluxed with stirring in the presence of palladium-charcoal or palladium black. The reaction may be followed by t.l.c.; after completion the catalyst is filtered off and washed with ethanol. If the product is a free peptide, it generally stays on the catalyst, from which it can be collected by repeated washing with water and evaporation of the washings in vacuo at $40{ }^{\circ} \mathrm{C}$. If acetic acid is used for dissolution then the product will be an acetate, which stays in solution in the ethanol, from which it can be recovered by evaporation. In either case the product needs minimal purification. Experimental details for two typical cases are described in the Experimental section, and relevant data concerning other peptides are incorporated in the Table.

These results demonstrate that $N$-benzyloxycarbonyl and $C$-terminal benzyl ester groups can be removed easily in the presence of $10 \%$ palladium-charcoal. The quantity of catalyst required is quite large but the catalyst can be re-used. In case of Z-Gly-Gly we carried out four hydrogenations with the same catalyst before

2 C. Gross, M. P. de Garilhe, A. Costopanagiotis, and R. Schwyzer, Helv. Chim. Acta, 1961, 44, 2042.

${ }^{3}$ D. J. Schafer, G. T. Young, D. F. Elliott, and R. Wade, $J$. Chem. Soc. $(C), 1971,46$. 
its efficiency decreased. $10 \%$ Palladium-charcoal can also be used for the removal of $N^{T}$-benzyl and benzyl ether groups, but the reaction time is longer. However, this can be considerably reduced by using freshly prepared palladium black catalyst, which must also be used for the removal of the nitro-group from a nitroarginyl peptide. The time required for this last reaction is much less than that for the usual catalytic hydrogenation, and the product is of greater purity. Indeed, for the removal of a nitro-group, transfer hydrogenation appears vastly superior to catalytic hydrogenation. This was evident for $1.5 \mathrm{~h}$. During this period the product Ser-Gly precipitated out. This was filtered off along with the catalyst, and the solid was washed with ethanol $(1 \times 10 \mathrm{ml})$ and water $(3 \times 10 \mathrm{ml})$. The aqueous washings were collected and evaporated in vacuo at $40{ }^{\circ} \mathrm{C}$ to yield Ser-Gly ( $\left.100 \mathrm{mg}, 90 \%\right)$ m.p. 208-210 ${ }^{\circ}$ (lit., ${ }^{4} 204-206^{\circ}$ ).

Boc-Phe-Arg-Trp-Gly, AcOH from Boc-Phe-Arg $\left(\mathrm{NO}_{2}\right)$-TrpGly.-To Boc-Phe-Arg $\left(\mathrm{NO}_{2}\right)$-Trp-Gly $(745 \mathrm{mg})$ in cyclohexene $(14 \mathrm{ml})$ was added ethanol $(28 \mathrm{ml})$; only a portion of the peptide dissolved and glacial acetic acid $(3 \mathrm{ml})$ was introduced to effect complete dissolution. To the resulting solution was added freshly prepared palladium black (75

\begin{tabular}{|c|c|c|c|c|c|}
\hline Substrate* & $\begin{array}{l}\text { Quantities of } \\
\text { (1) substrate }(\mathrm{mg}) \text {, } \\
\text { (2) catalyst }(\mathrm{mg}) \text {, } \\
\text { (3) cyclohexene }+ \\
\text { ethanol (ml) }\end{array}$ & $\begin{array}{l}\text { Reaction } \\
\text { time } \\
\text { (h) }\end{array}$ & Product & $\begin{array}{l}\text { Yield } \\
(\%)\end{array}$ & $\begin{array}{c}\text { M.p. }\left({ }^{\circ} \mathrm{C}\right) \\
\text { Found } \\
\text { (Reported) }\end{array}$ \\
\hline Z-Gly-Gly & (1) 150, (2) $75, \ddagger(3) 3+6$ & 2 & Gly-Gly & 80 & + \\
\hline Z-Ser-Gly-OBzl a & (1) 180, (2) $90, \ddagger$ (3) $4+8$ & 1.5 & Ser-Gly & 90 & $\begin{array}{c}208-210 \\
(204-206)\end{array}$ \\
\hline Z-Pro-Val-Gly-OEt $t^{b}$ & (1) 500, (2) $250, \ddagger(3) 6+12$ & 1.5 & Pro-Val-Gly-OEt & 84 & $\begin{array}{c}125-128 \\
(127-128)^{b}\end{array}$ \\
\hline Z-Ala-Asp(OBzl)-Ser-Gly ${ }^{c}$ & $\left\{\begin{array}{l}(1) 100,(2) 50, \ddagger(3) 2+4 \S \\
(1) 100,(2) 20,9(3) 2+4 \S\end{array}\right.$ & 0.75 & $\begin{array}{l}\text { Ala-Asp-Ser-Gly, } \\
\text { AcOH }\end{array}$ & 93 & $\begin{array}{c}192-196 \\
(190-194)^{c}\end{array}$ \\
\hline Boc-Lys $(Z)$ & (1) $100,(2) 50, \pm(3) 2+4$ & 1.5 & Boc-Lys & 95 & $\begin{array}{l}199-200 \\
(200-201)^{d}\end{array}$ \\
\hline Boc-Phe-Arg $\left(\mathrm{NO}_{2}\right)-$ Trp-Gly ${ }^{\circ}$ & $\left\{\begin{array}{l}(1) 400,(2) 200, \ddagger(3) 8+16 \S \\
(1) 745,(2) 75, \rrbracket(3) 14+28 \S\end{array}\right.$ & $\begin{array}{l}24 \\
6 \\
8\end{array}$ & $\begin{array}{l}\text { Boc-Phe-Arg-Trp-Gly } \\
\text { AcOH }\end{array}$ & $\begin{array}{l}77 \\
88\end{array}$ & $175-180^{* *}$ \\
\hline $\operatorname{Boc}-\mathrm{His}\left(N^{\tau}-\mathrm{Bzl}\right)$ & $\left\{\begin{array}{l}(1) 100,(2) 50, \ddagger(3) 2+4 \\
(1) 100,(2) 50, \uparrow(3) 2+4\end{array}\right.$ & 3 & Boc-His & 91.5 & $\frac{190-192}{(191.5)^{f}}$ \\
\hline Boc-Tyr(Bzl) & $\left\{\begin{array}{l}(1) 100,(2) 50,+(3) 2.5+5 \\
(1) 75,(2) 25, \rrbracket(3) 2+4\end{array}\right.$ & $\begin{array}{l}7 \\
3\end{array}$ & \} Boc-Tyr & $\begin{array}{l}90 \\
93\end{array}$ & $\begin{array}{l}135-137 \\
(136-138)\end{array}$ \\
\hline Z- $\beta$-Ala-Tyr-Ser-Met-OMe ${ }^{\circ}$ & (1) $50,(2) 20$, (3) $2+5$ & 1 & $\begin{array}{l}\beta \text {-Ala-Tyr-Ser-Met- } \\
\text { OMe }\end{array}$ & 90 & $128-130 * *$ \\
\hline $\begin{array}{l}\text { Asn-Glu(OBzl)-Glu(OBzl)-Gly-Leu- } \\
\text { Phe-Gly-Gly-Arg }\left(\mathrm{NO}_{2}\right) \text {-OBzl e }\end{array}$ & (1) $30,(2) 10, \pi(3) 1+3 \S$ & 6 & $\begin{array}{l}\text { Asn-Glu-Glu-Gly- } \\
\text { Leu-Phe-Gry-Gly- } \\
\text { Arg-2AcOH } \dagger \dagger \\
\text { (Fibrinopeptide } \\
\text { B of green } \\
\text { monkey) }\end{array}$ & 83 & $\dagger^{e}$ \\
\hline
\end{tabular}

\begin{abstract}
* Except for glycine, the amino-acids in these peptides are of the L-variety. † Identical with an authentic sample. $\ddagger 10 \%$ Pd-C. If Freshly prepared palladium black. § Acetic acid added until dissolution. ** Satisfactory elemental analyses have been obtained for peptides not previously reported. †† For the removal of ammonium acetate formed during the hydrogenation, gel filtration of this peptide over LH-20 was carried out.

${ }^{a}$ Ref. 4. ${ }^{b}$ R. Schwyzer and W. Rittel, Helv. Chim. Acta, 1961, 44, 159. ' ${ }^{\circ}$ G. M. Anantharamaiah and K. M. Sivanandaiah, Current Sci., 1974, 43, 245. ' R. Schwyzer, A. Costopanagiotis, and P. Sieber, Helv. Chim. Acta, 1963, 46, 870. ' Ref. 5. $f$ B. O. Handford, T. A. Hylton, K. T. Wang, and B. Weinstein, J. Org. Chem., 1968, 33, 4251. ${ }^{g}$ G. W. Anderson and A. C. McGregor, J. Amer. Chem. Soc., 1957, 79, 6180.
\end{abstract}

from the hydrogenation of nitroarginyl peptides other than those listed in the Table. This method, unlike catalytic hydrogenation, is also useful for the removal of $N$-benzyloxycarbonyl group from peptides having sulphur-containing amino-acids. The t-butoxycarbonyl group is unaffected under these conditions.

\section{EXPERIMENTAL}

Ser-Gly from Z-Ser-Gly-OBzl.-A mixture of Z-Ser-GlyOBzl (180 mg), 10\% palladium-charcoal $(90 \mathrm{mg})$, cyclohexene $(4 \mathrm{ml})$, and ethanol $(8 \mathrm{ml})$ was refluxed with stirring

- K. Noda, M. Besho, T. Kato, and N. Izumiya, Bull. Chem. Soc. Japan, 1970, 43, 1834. $\mathrm{mg}$ ) and the mixture was refluxed with stirring until the protected compound had disappeared (t.l.c.) $(c a .6 \mathrm{~h})$. The mixture was then filtered and the filtrate evaporated in vacuo at $40^{\circ} \mathrm{C}$. The residue was washed with water (to remove ammonium acetate), dried, and reprecipitated from methanol-ethyl acetate to yield Boc-Phe-Arg-Trp-Gly,AcOH $(670 \mathrm{mg}, 88 \%)$, m.p. $175-180^{\circ} .^{5}$

We thank the Council of Scientific $x$ Industrial Research, Government of India, for financial support.

[6/1214 Received, 22nd June, 1976]

5 G. M. Anantharamaiah and K. M. Sivanandaiah, unpublished work. 